\begin{tabular}{|l|l|l|l|l|}
\hline Int. Revue ges. Hydrobiol. & $\mathbf{6 2}$ & $\mathbf{4}$ & 1977 & $511-521$ \\
\hline
\end{tabular}

\author{
G. Winfield Fatrchild, Richard S. Stemberger, \\ Lawrence C. Epskamp, and Henry A. Debaugh
}

The University of Michigan Biological Station

Pellston, Michigan

\title{
Environmental Variables Affecting Small-Scale Distributions of Five Rotifer Species in Lancaster Lake, Michigan ${ }^{1}$
}

\begin{abstract}
The small-scale distributions of the rotifers Polyarthra vulgaris, Synchaeta stylata, Conochilus unicornis, Hexarthra mira, and Asplanchna priodonta were investigated in Lancaster Lake, Cheboygan County, Michigan, July 21, 1974. Measurements were taken for 13 depths (at 1-m intervals) and at 4 times of the day (1:00 AM, 7:00 AM, 1:00 PM, and 7:00 PM). In addition, the abundances of 6 crustacean, 2 planktonic dipteran, and 10 algal species, as well as temperature, light, oxygen, chlorophyll $a$, alkalinity, $\mathrm{pH}$ and free carbon dioxide were measured. Whereas abiotic factors appeared to control large scale occupation of the lake, and excluded most species from the deeper portions of the hypolimnion, small-scale distributional variation of the rotifers depended upon biotic interactions, particularly with the crustacean zooplankton.
\end{abstract}

Contents

1. Introduction ............................. 511

2. Materials and Methods . . . . . . . . . . . . . . . . . . . . . 512

3. Results . . . . . . . . . . . . . . . . . . . . . . . 512

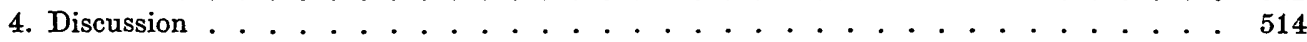

5. Summary . . . . . . . . . . . . . . . . . . . . . . 519

6. Acknowledgements . . . . . . . . . . . . . . . . . . . . 520

7. References . . . . . . . . . . . . . . . . . . . . . . . 520

\section{Introduction}

Although species distributions in the crustacean zooplankton have been well documented in a number of extensive lake studies, information concerning diurnal migration, vertical distribution and horizontal patchiness in the Rotatoria remains very incomplete. Notable contributions have been made by BERzINS (1958), CAMPBELL (1941), Kosicri (1960), Gilyarov (1965), and Dumont (1972), as weil as Larsson (1971), Pejler (1957, 1965), Ruttner-Kolisko (1974, 1975a, 1975 b), Ruttner (1905, 1943), and George and Fernando $(1969,1970)$. However, these works have left unclear the relative effects of chemical and physical variables, and particularly of biotic interactions, upon small-scale rotifer distributions. The present study attempts to identify those variables and their correlations with the abundances of Polyarthra vulgaris, Synchaeta stylata, Conochilus unicornis, Hexarthra mira, and Asplanchna priodonta.

1 This paper represents a contribution from The University of Michigan Biological Station. 


\section{Materials and Methods}

Lancaster Lake, Cheboygan County, Michigan ( $\mathbb{N} 45^{\circ} 37^{\prime}, W^{\prime} 84^{\circ} 43^{\prime}$ ), possesses a distinct thermocline and clinograde oxygen curve during the summer months, and is colored with limnohumic acids, derived from drainage through adjacent cedar swamp vegetation. The light compensation depth is approximately $4 \mathrm{~m}$. The lake is of ice block origin, having a single basin with maximum depth of $17.4 \mathrm{~m}$ and a surface area of $9.8 \mathrm{ha}$. In some years the lake displays meromixis, attributable to its low surface-to-volume ratio and wind sheltered location.

Samples for physicochemical measurements were collected with a 3 -liter Kemmerer bottle at 1:00 AII, 7:00 AM, 1:00 PM, and 7:00 PM, July 21, 1974, at 1-m intervals to a clepth of $12 \mathrm{~m}$. Two hundred $\mathrm{ml}$ from each sample were preserved in Lugol's solution for phytoplankton enumeration. Temperature was measured with a standard resistance thermometer, and total light penetration was recorded with a submarine photometer equipped with a Weston cell. Dissolved oxygen was determined titriometrically by the ALSTERBERG (Azide) modification of the WINIKLER method (APHA 1971). Total alkalinity was determined titriometrically (APHA 1971), pH obtained with a Beckman model $\mathrm{N}$ field $\mathrm{pH}$ meter, and free carbon dioxide calculated from the $\mathrm{pH}$ and alkalinity data with a nomagraph. Chlorophyll $a$ concentrations were determined with a Turner Model III fluorometer (HoLM-HANSEN et al. 1965).

Zooplankton samples were obtained with a 12.8-liter SchindLer-PATALAS plankton trap. The zooplankton were anaesthetized with carbonated water and preserved with $\mathbf{5}^{\prime \prime}$." buffered formalin.

Two counting techniques were employed for the zooplankton. Total counts of each sample were made of the less abundant species (Daphnia pulex, Chaoborus spp., Bosmina longirostris, Asplunchna priodonta, Diaptomus reighardi, Tropocyclops prasinus, Mesocyclops edax, Cyclops bicuspidatus thomasi) with the use of a modified Bogorov counting chamber (GANNon 1971).

Polyarthra vulgaris, Hexarthra mira, Synchaeta stylata, Conochilus unicornis and the copepod nauplii were counted by first reducing all samples to $50 \mathrm{ml}$; three 1 -ml subsamples were then extracted with an automatic pipet and combined in a plexiglass counting cell (STEMBERGER 1974). Two such pooled subsamples were used, resulting in coefficients of variation below $10^{\prime \prime}$ ", for all but the very small mean values.

Phytoplankton counts were performed with a .01-ml PALMER-MaLONEY counting .chamber (STErs 1973). Samples were adjusted to $5.0 \mathrm{ml}$ and enumerated under a compound microscope $(430 \mathrm{X})$. Three, or occasionally two, subsamples were counted; coefficients of variation rarely exceeded $15^{\circ} \%$.

\section{Results}

The diel distributions of the plankton species studied (figs. 1 and 2) indicated that more than $90 \%$ of their abundances (with the significant exceptions of Cryptomonas erosa and the small flagellates Chlamydomonus and Rhodomonas spp.) existed in the upper $9 \mathrm{~m}$ of the water column. Values included in the data analysis (Tab)les 1 and 2) refer to samples taken from 0-9 $\mathrm{m}$. All species abundances were log-transformed to improve normality.

Temperature, oxygen, and free carbon dioxide (fig. 3) were highly intercorrelated; a single principal component (PC) accounted for $91.5^{\prime \prime}, 0$ of their observed variance $(\mathrm{PC}=.59 \mathrm{Temp} .+.56 \mathrm{Oxy}-.58 \mathrm{CO}$; eigen value $=2.744)$. Separate effects of these three variables could not be dissociated. The single resultant variable, however, is highly correlated with the relative exclusion of most plankton species from the deeper portions of the hypoliminion.

Most of the plankton species distributions were consistent with previous literature. Daphnia pulex, Diaptomuss reighardi and the two species of Chuoborus (C. flavicans, C. punctipennis) all showed pronounced upward migration at night. The adult Cyclops bicuspidatus thrmasi were consistently found in the hypolimnion; cyclopoid copepodids, in contrast, were largely found in the epilimnion and thermocline. Cope- 

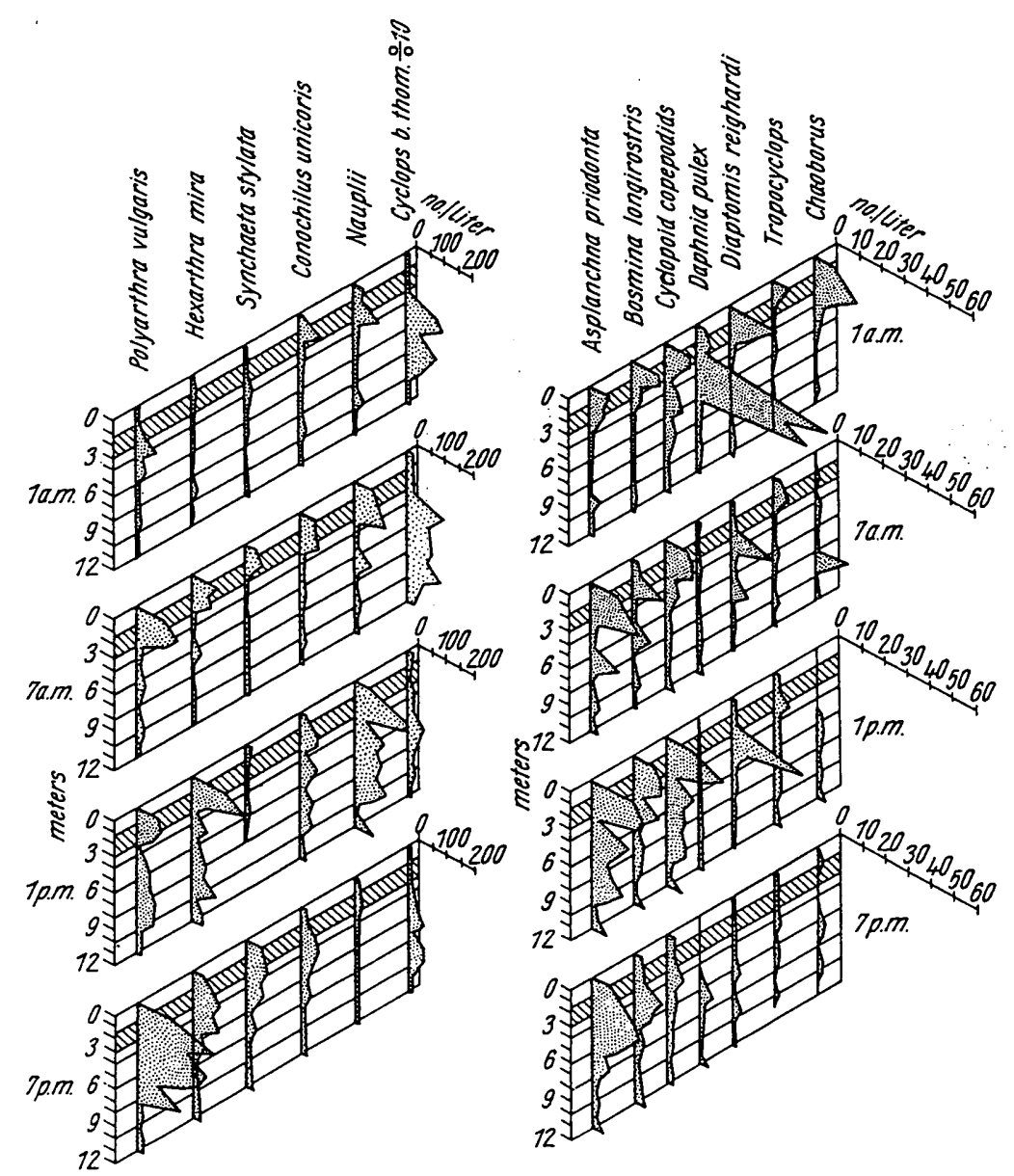

Fig. 1. Abundances of the major zooplankton species for 13 depths and 4 times of the day in Lancaster Lake, Michigan, July 21, 1974. Termocline indicated with hatching.

pod nauplii were distributed, like the rotifers, in the upper portion of the water co. Jumn.

The high concentrations of chlorophyll $a$ in the hypolimnion (fig. 4), below light levels detectable by the Weston submarine photometer, are attributed to Cryptomonas erosa and Chlamydomonas and Rhodcmonus spp., which are known facultative heterotrophs (Hutchinson 1967). Cryptomonas erosa was a major component of Ir.MavirTa's (1974) study of the diel periodicity of phytoplankton in Lake Pääjärvi, Finland. A marked downward migration during the daylight hours, similar to the pattern shown in the present study, was attributed to negative phototaxis. Most other algal species, particularly the diatoms, were concentrated at or above the bottom of the thermocline.

The distributions of the five rotifer species displayed considerable similarity (Table 1). A summation of the five species abundances for each sample was correlated with the distributions of the crustacean zooplankton and with physical/chemical variables (Table 2).

The small filter-feeding crustacea Bosmina longirostris, Tropocyclops prasinus, and the copepod nauplii similarly showed a high degree of intercorrelation. This 


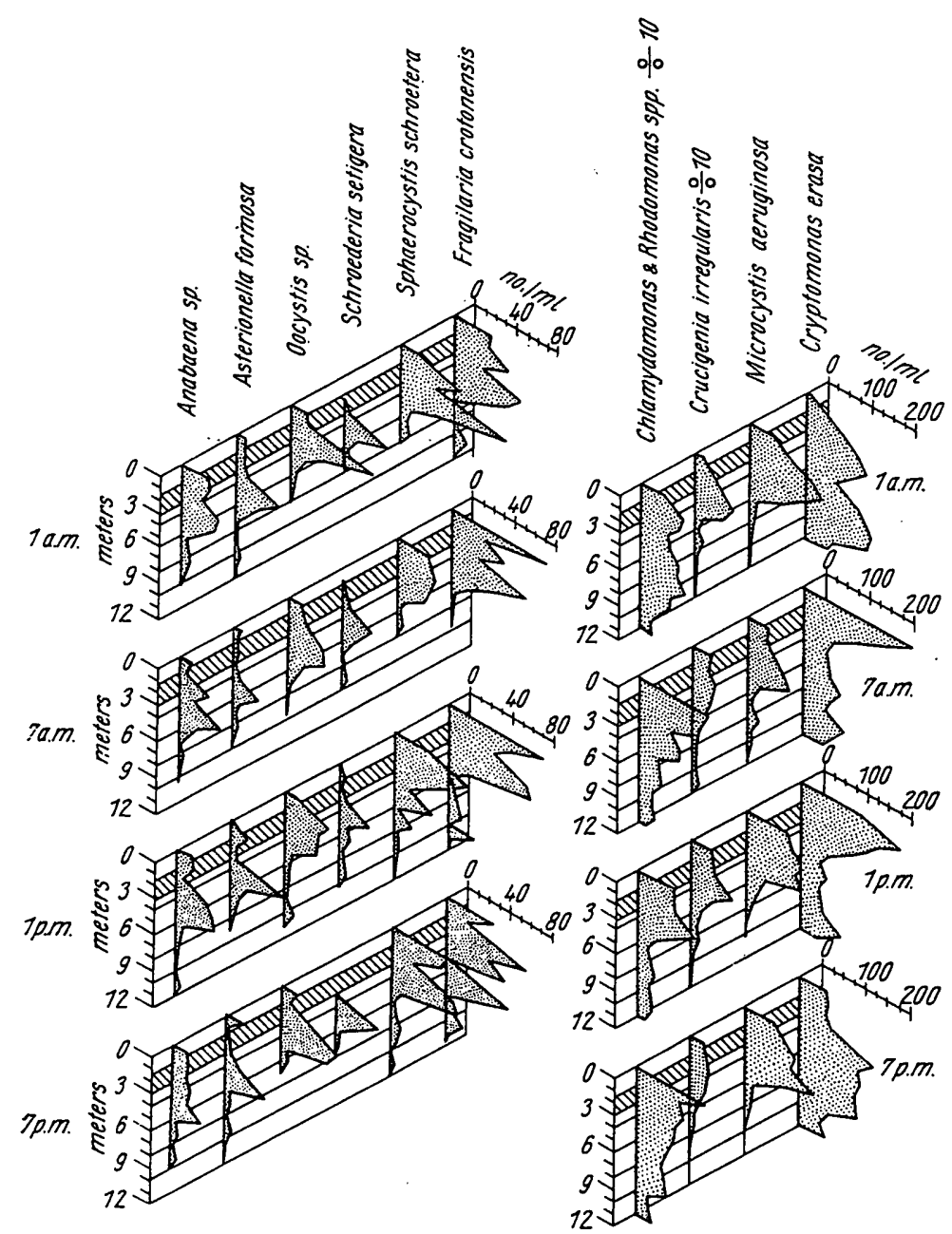

Fig. 2. Abundances of the major phytoplankton species for 13 depths and 4 times of the day in Lancaster Lake, Michigan, July 21, 1974. 'Thermocline indicated with hatching.

"small crustacean" community, consisting of the summed abundances of the three taxa, showed high correlation with the rotifers. Rotifer abundances also showed high, but less consistent, positive correlations with chlorophyll $a$ and an inverse relationship with adult Cyclops bicuspidatus thomasi and Diaptomus reighardi. Whereas the small zooplankton species were highly associated in their distributions, the large crustacea were much less closely associated (fig. $\mathbf{t}$ ).

\section{Discussion}

The five rotifer sjecies chosen for the st udy are all common components of fresh water lakes in North America. Conochilus unicumis displayed slight diurnal nigration in lake 122 of the ErA Jalses (SCHINDLER and Noris 1971), with maxima both at the surface and at 4 meters. liutTres (1905) reported that the species rose to the surface 

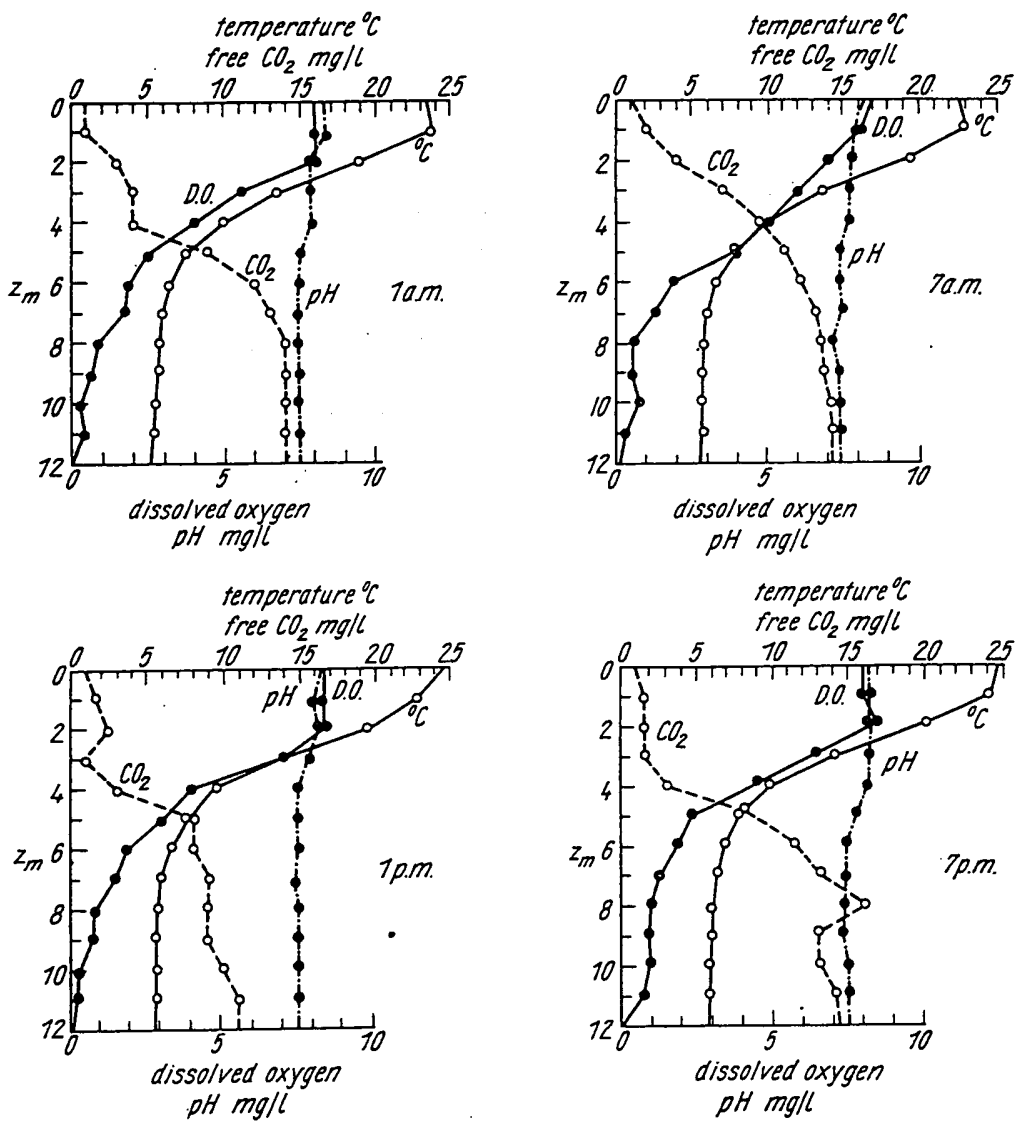

Fig. 3. Physical and chemical measurements taken concurrently with the plankton samples for 13 depths and 4 times of the day in Lancaster Lake, Michigan, July 21, 1974.

at night in the Grosser Plöner See. The species is a detritivore (N.AUwercK 1963) or nannoplanktivore, and possesses malleoramate trophi. The population in Lancaster Lake was concentrated near the surface at night, but was more uniformly distributed in the water column during the daylight hours.

SCHINDLER and Novín (1971) reported that Polyarthra vulgaris occurvied the lower depths (6-10 m) of lake 122 on June 21, 1968, and the top three meters on August 26, 1968. GEORGE and FERNANDo (1969) noted that the P. vulgaris population of Sunfish Lake, Ontario, remained in the hypolimnion during the months of June and July after stratification had occurred, but consistently occurred in the epilimnion during August and September. Oxygen depletion in the hypolimnion was the most probable cause for this change. They also observed that the species exhibited an early evening migration to the surface in June, July, August, and February, with subsequent sinking during the night, but a reverse pattern in March and April. They suggested that temperature, oxygen, and light regimes may have initiated this migratory behavior. PENNAK's (1944) study of five lakes in Colorado failed to uncover diurnal migration of any sort by the species. Berzin's (1958: discussed in Hutchissos 1967) study of Iaake Skarshultsjön deseribed maxima in the epilimnion. PEJLer (1957) suggested that the specics is more positively phototrophic than most planktonic roti- 

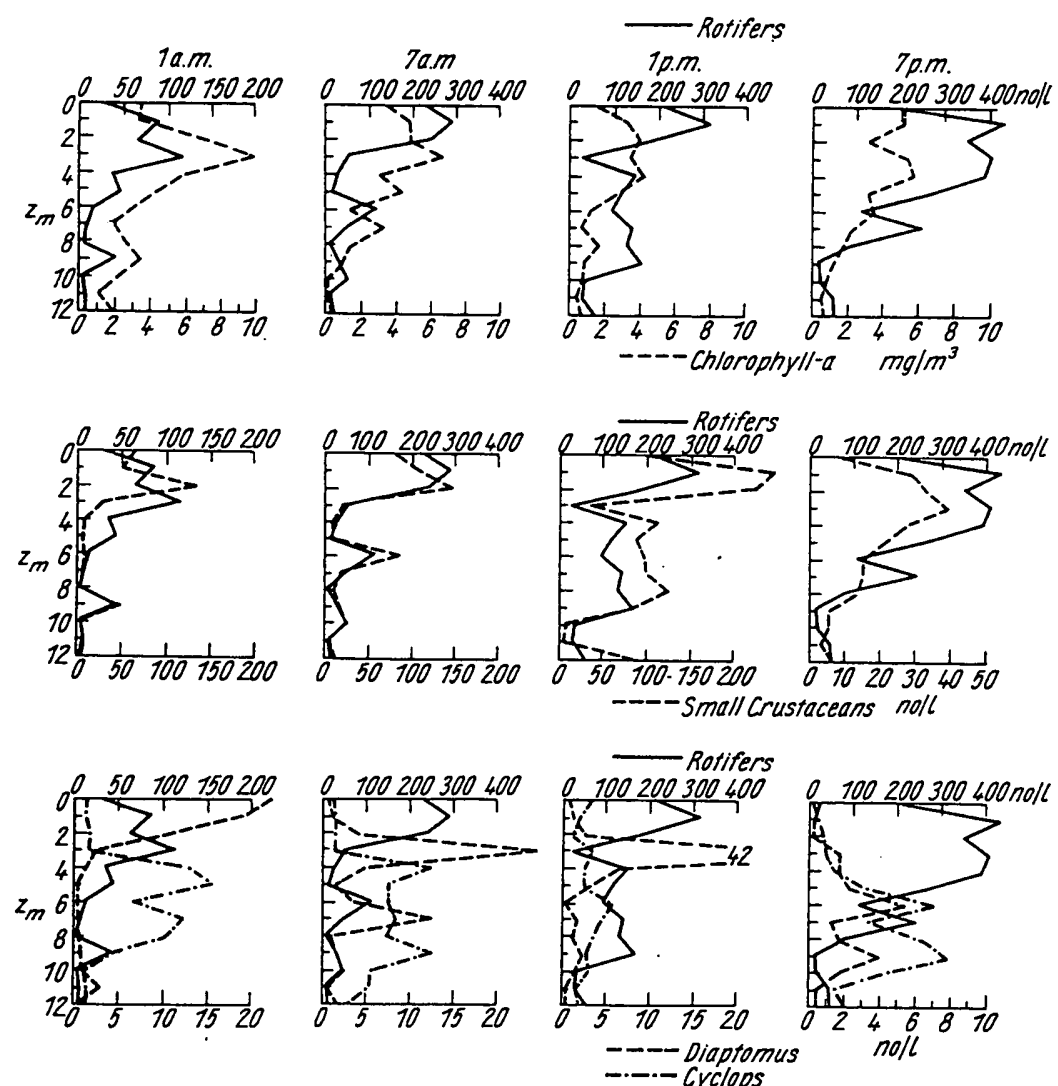

Fig. 4. Comparisons of the microdistribution of the rotifer community with chlorophyll $a$ concentration, the distribution of the small crustacea, and the distributions of two dominant, large copepod species in Lancaster Lake, Michigan, July 21, 1974.

Table 1. Correlation matrix of log-transformed rotifer distributions, July 21, 1974, in Lancaster Lake. (Absolute values exceeding .402 indicate significance at $P<.01$ )
Polyarthra
Synchaeta
1.000
Hexarthra
Conochilus
.738
.813
.707
A.splanchna
.759
Total Rotifers

$$
\begin{aligned}
& .555 \\
& .437 \\
& .524 \\
& .635
\end{aligned}
$$$$
1.000
$$
Polyarthra Synchaeta

1.000
.846
.913
.935

1.000
.874
.895
1.000
Hexurthra Conochilus Asplunchna Total Rotifers

fers, and, like George and Fernaxdo $(1960,1970)$, attributed its exclusion from the hypolimnion in late summer to oxygen depletion. Our data support George and FERNANDO's observations of a night time sinking. P. vulgaris is termed a specialist upon the larger cryptomonads (EDMONDson 1965). Similar observations were made by Pourriot (1965), who also cited the work of earlier authors. The high numerical abundance of $P$. vulguris in Lancaster Lake at a time when Cryptomonus erosu was a dominant phytoplankter is considered significant. NAUWERCK (1963) has suggested that the species may utilize smaller particles as well. 
Table 2. Correlation matrix of the rotifer community, crustacean species, and environmental variables. (Absolute values exceeding .402 indicate significance at $P<.01$ )

Total Rotifers
Diaptomus
Cyclops
Mlesocyclops
Copepodids
Daphnia
Chaoborus
Bosmina
Nauplii
Tropocyclops
Chlorophyll a
Diss. Oxygen
Temperature
Free CO.
Light

\begin{tabular}{|c|c|c|c|c|c|c|c|c|c|c|c|c|c|c|}
\hline 1.000 & & & & & & & & & & * & & & & \\
\hline .124 & 1.000 & & & & & & & & & & & & & \\
\hline-.672 & -.121 & 1.000 & & & & & & & & & & & & \\
\hline .224 & .737 & -.101 & 1.000 & & & & & & & & & & & \\
\hline .526 & .067 & -.344 & .263 & 1.000 & & & & & & & & & & \\
\hline-.410 & .026 & .486 & -.138 & -.209 & 1.000 & & & & & & & & & \\
\hline-.149 & .260 & .159 & .076 & -.145 & .689 & 1.000 & & & & & & & & \\
\hline .834 & .356 & -.560 & .752 & .579 & -.326 & -.032 & 1.000 & & & & & & & \\
\hline .732 & .272 & -.458 & .461 & .686 & -.384 & -.046 & .760 & 1.000 & & & & & & \\
\hline .729 & .385 & -.398 & .417 & .615 & -.255 & .005 & .752 & .883 & 1.000 & & & & & \\
\hline .164 & .175 & -.430 & .081 & .113 & .049 & .106 & .173 & -.036 & -.012 & 1.000 & & & & \\
\hline .492 & .236 & -.641 & .224 & .442 & -.235 & .039 & .493 & .339 & .339 & .699 & 1.000 & & & \\
\hline .549 & .150 & -.769 & .145 & .541 & -.357 & .007 & .534 & .453 & .381 & .552 & .862 & 1.000 & & \\
\hline-.592 & -.170 & .753 & -.169 & -.568 & .409 & -.061 & -.620 & -.490 & -.441 & -.454 & -.820 & -.933 & 1.000 & \\
\hline .409 & -.161 & -.527 & .005 & .514 & -.616 & -.417 & .368 & .462 & .291 & .165 & .519 & .717 & -.712 & 1.000 \\
\hline 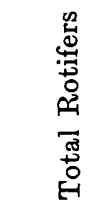 & 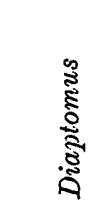 & 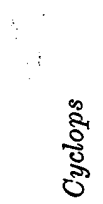 & 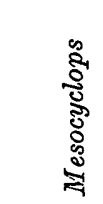 & 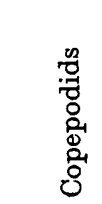 & 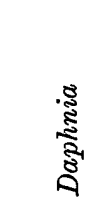 & 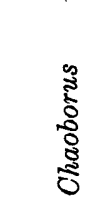 & 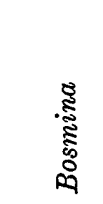 & 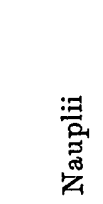 & 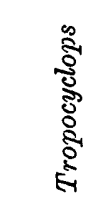 & 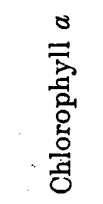 & 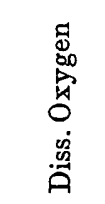 & 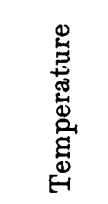 & 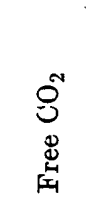 & 莡 \\
\hline
\end{tabular}


Thienteman (1919) observed that Hexurthra mira exhibited a marked downward movement at nightfall in the Ulmener Maar. MrracLE (1974) made reference to the colonization of the hypolimnion by this species during the summer months in Banyolas Lake, Spain. Diurnal migration for the species was not evident in Lancaster Lake. The species possesses malleoramate trophi similar to those of Conochilus unicomis, with which its distribution was also highly correlated.

Ilutchinson (1967) describes Synchaetu stylutu as a late summer species. The population in Lancaster Lake migrated $2-3 \mathrm{~m}$ downward at night, as did $P$. rulguris. Both species possess virgate trophi, and their food selection might be expected to be similar. Three other species of the genus have been raised successfully on Cryptomoncus orutu in the laboratory by POURRiot (1965), who also mentions Mullomonus and centric diatoms as part of the Synchaetid diet.

Asplanchna priodonta exhibited reverse migration in Lake Donk (Demosir 1972), probably a result of interspecific a voidance of the coexisting crustacean species. The species was concentrated at the surface at night in Lancaster Lake, with maximum concentrations several meters below the surface during the daylight hours. A. priodontu is a well known predator upon smaller rotifers such as Kerutellu and Bruchionus, apparently capturing its prey by "random encounters" (PouRRIOT 1965), hut consumes a wide variety of large algal species, including Peridinium and some diatons (NAUWERCK 1963) as well. The distribution of $A$. priodonta followed verr closely that of the algivorous rotifers in Lancaster Lake.

Microdistributional variation in rotifer abundance was considerable in Lancaster Lake, as well as in previous lakes studied. Such variation is unexplainable solely in terms of such smoothly changing variables as temperature, oxygen, or light. RotrNERKolisko (1975a) has stated: "One gets the impression that the migration pattern is not specific for a particular species, but changes from one lake to the other, and also within one biotope, according to the momentary environmental situation." Our results suggest that such microdistributional variation may be a function of biotic interactions with other plankton species.

The microdistributional correlations between species in Lancaster Lake may imply a number of cause-effect relationships:

(1) P'redators may be found together with their prey, but eliminate the prey species at very low rates, generating a high positive correlation. Such a relationship is hypothesized as the cause underlying the high positive, though inconsistent, relationship between the rotifers and phytoplankton biomass assessed as chlorophyll $a$. The work of NAUWERCK (1959) and ERMAN (1956) suggests that rotifers may filter ahout $.001 \mathrm{ml}$ of water per hour. Thus, even at the highest rotifer densities observed, rerduction of algal standing crop would be minimal.

(2) Predators may be capable of locating their prey, but eliminate the prey species at sufficiently rapid rates to generate a high negative correlation. The high negative correlation of adult Cyclops bicuspidatus thomasi with the rotifer community in Lancaster Iake might be interpreted as such a relationship. Experimental studies of feeding rates by $C$. bicuspidatus thomasi, however, indicate an average rate of less than 1 (MCQUEEN 1969) to as many as 6 (ANDERSON 1970) prey per predator taken per day, an amount hardly sufficient to account for high mortality in the rotifers, and not a sufficient explanation of the inverse correlation.

(3) Prey species may detect and aroid concentrations of potential predators. Implied by such a relationship are both the sensory perceptive capacities and motility for avoidance by the prey species. Demont (1972), in a study of the reverse migration of Asplanchna priodonta in the shallow eutrophic Lake Donk, Eastern Flanders, Belgium, suggested that the "stimulus [for reverse migration] might very well be within the organisms themselves, i. e., that the presence of one species in large numbers 
might force the other to behave in an unusual way." Dumont concluded that the avoidance reaction by Asplanchna was proportional to the "robustness" of the crustacean species. STRICKLER and BAL (1973) have demonstrated the existence of such mechanoreception and behavioral avoidance reactions in the crustacean copepods. The existence of sinular sensory capacities appears highly plausible in most zooplankton species. The maxinum rate of vertical migration of $P$. vulgaris has been calculated (GEORge and Fernando 1970) at about .3-.4 m/hour. The fins of Polyarthra may permit escape from predators (AlLEN 1968). The appendages of $H$. mira may have a similar function. The extent to which escape velocities exceed normal swimming and the duration of such behavior are unknown, however. In a heterogeneous environment consisting, apparently, of very small patches, the avoidance capacities of even the relatively weak swimming rotifers and small crustacea is likely to be significant.

(4) Organisms may be correlated indirectly, either positively or negatively, by their mutual response to a third environmental variable. For example, whereas late instar Chaoborus larvae are known predators upon smaller Duphnia (FEDERENko 1975a, b), the high positive correlation between them is better interpreted as a mutual response to light.

(5) Reproduction in the phytoplankton (VOLLENWEIDER 1969) and smaller zooplankton species (ALLAN 1976) may be important in determining large-scale variations in species abundances. Egg development time in Hexarthra fennica (RUTTnsRKolIsko $1975 \mathrm{~b}$ ), for example, is halved with each $5{ }^{\circ} \mathrm{C}$ increase in temperature; assuming a similar relation in other rotifer species, reproductive capacity near the surface of Lancaster Lake may be more than four times as great as in the hypolimnion.

Reproduction related to temperature can be important in generating high correlations between species on a large scale, but is unsatisfactory in explaining microdistributional patchiness within a particular species. Differential reproduction due to differences in food availability is also too slow to account for diel microdistributional variation.

(6) Horizontal or vertical transport due to currents may induce significant correlations as a result of differential swimming ability of organisms desiring to maintain a preferred environmental condition such as temperature or light level. Because of Lancaster Lake's wind-sheltered location, the effects of wind-generated currents on distributions are probably minimal, especially below $2 \mathrm{~m}$ in the metalimnion.

The high positive and negative correlations between species abundances in Lancaster Lake (Figs. 1 and 2) suggest that biotic interactions may strongly modify basic behavioral responses to such physico-chemical conditions as light and oxygen concentration to the extent that future studies of vertical distribution must be synecological in approach, considering all major components of the plankton community.

\section{Suimmary}

The diurnal microdistributional patterns of 5 species of rotifers were examined in Lancaster Lake, Michigan on July 21, 1974. A total of 24 physical, chemical and biotic variables most relevant to the rotifer distributions were measured. The following conclusions emerge:

(1) Considerable patchiness, both horizontal and vertical, was evident for all plankton species.

(2) The large scale and microdistributions of the rotifers, including the predacious Asplanchna priodonta, were highly sinilar.

(3) The small crustacea (Bosmina, Tropocyclops, and the copepod nauplii) were highly correlated with the distribution of the rotifers. 
(4) All of the small zooplankton species exhibited inverse correlations with the large crustacea, particularly the predatory copepod Cyclops bicuspidutus thomasi. They also showed positive, but inconsistent, correlations with phytoplankton concentrations.

(5) Whereas abiotic factors such as temperature and oxygen undoubtedly excluded the rotifers as well as other zooplankton species from the lower portion of the water column, microdistributional variation from the epilimnion to the upper waters of the hypoliminion could best be explained in terms of interactions between plankton species.

(6) Specifically, the reverse diurnal migration of rotifer species hypothesized by previous authors, which has been explained as a response to abiotic factors such as light, may be associated with avoidance of the larger crustacean species, and microdistribution should thus logically vary according to the constitution of the zooplankton community.

\section{Acknowledgements}

The authors wish to thank Dr. JoHN E. GANNON for his support and encouragement during the course of this study, and the University of Michigan Northern Michigan Environmental Research Program for the generous sharing of previous data concerning Lancaster Lake. We also thank Dr. E. F. Stoermer for his assistance in phytoplankton identification.

\section{References}

Amer. Publ. Health Assoc., 1971: Standard methods for the examination of water and wastewater. 13 th ed.

AlldN, J. D., 1976: Life history patterns in zooplankton. - Am. Natur. 110: 165-180.

Allen, A. A., 1968: Morphology of the planktonic rotifer Polyarthra vulgaris. - Trans. Amer. Microsc. Soc. 87 : 60-69.

Anderson, R.J., 1970: Predator-prey relationships and predation rates for crustacean zooplankters from some lakes in western Canada. - Can. J. Zool. 48: 1229-1240.

Berziss, B., 1958: Ein planktologisches Querprofil. - Rep. Inst. Freshw. Res. Drottningholm. 39: $5-22$.

CAMPBell, R. S., 1941 : Vertical distribution of the plankton Rotifera in Douglas Lake, Michigan, with special reference to depression individuality. - Ecol. Monogr. 11: 1-19.

Dumont, H. J., 1972: A competition-based approach of the reverse vertical migration in zooplankton and its implications, chiefly based on a study of the interactions of the rotifer $A s$ planchna priodonta (GOSSE) with several crustacea Entomostraca. - Int. Revue ges. Hydrobiol. 57 : 1-38.

Erman, L.A., 1962: On the quantitative aspects of feeding and selection of food in the planktonic rotifer Brachionus calyciflorus Pallas. - Zool. Zh. 11 : 34-47.

Federenko, A. Y., 1975a: Instar and species-specific diets in two species of Chroborus. - Limnol. Oceanogr. 20:238-249.

- 1975b: Feeding characteristics and predation impact of Chaoborus (Diptera, Chaoboridae) larvae in a small lake. - Limnol. Oceanogr. 20: 250-58.

Gannon, J. E., 1971: Two colinting cells for the enumeration of zooplankton microcrustacea. Trans. Amer. Microsc. Soc. 90: 486-490.

George, M. G., and C. H. Fernando, 1969: Seasonal distribution and vertical migration of planktonic rotifers in two lakes in eastern Canada. - Verh. Intern. Verein. Limnol. 17: 817-829.

- 1970: Diurnal migration in three species of rotifers in Sunfish Lake, Ontario. - Limnol. Oceanogr. 15: 218-223.

Gilyarov, A. M., 1965: Vertical distribution of plankton rotifers (Rotatoria) in the Bolshoe Eremeyevshoye Lake Island Velikey, Kandalaksha Bay, White Sea. - (transl.) Zool. Zh. 44: $688-92$.

Holy-Hansen, O., C. J. Lorenzen, R. W. Holdres and J. D. H. Strickilatd, 1965: Fluorometric determination of chlorophyll. - J. Cons. perm. int. Explor. Mer. 30: 1-15. 
Hutchinson, G. E., 1967: A Treatise on Limnology. - Vol. 2. Wiley, ג. Y.

ItMavirTA, V., 1974: Diel periodicity in the phytoplankton community of the oligotrophic Lake Pääjärvi, southern Finland. I. Phytoplankton primary production and related factors. - Ann. Bot. Fennici 11: 151-176.

FosickI, S., 1960: The vertical distribution of pelagic Rotatoria during the summer stagnation in lakes M. Kolajki and Sniardivy. - Polsk. Arch. Hydribiol. s: 9-61 (in Polish).

LARsson, P., 1971: Vertical distribution of planktonic rotifers in a meromictic lake. - Norv. J. Zool. 19: 47-75.

MCQUEen, D. J., 1969: Reduction of zooplankton standing stocks by predacious Cyclops bicuspidatus thomasi in Marion Lake, British Columbia. - J. Fish Res. Bd. C'an. 26: 1605-1618.

IIRACLE, M. R., 1974: Niche structure in freshwater zooplankton: A principal components approach. - Ecology อ̈อ̆ : 1306-1316.

N.AUwerck, A., 1963: Die Beziehungen zwischen Zooplankton und Phytoplankton im See Erken. Symb. bot. Upsaliens. 17: 1-163.

Pejler, B., 1957: Taxonomical and ecological studies on planktonic Rotatoria from northern Swedish Lapland. - K. Svenska Vetensk. Akad. Hand. 6: 1-68.

- 1965: Regional-ecological studies of Swedish freshwater zooplankton. - Zool. Bidr. Upps. 36: $407-515$.

Pennak, R. W., 1944: Diurnal movements of zooplankton organisms in some Colorado mountain lakes. - Ecology 25: 387-403.

Pourriot, R., 1965: Recherches sur l'écologie des Rotifères. - Vie et Milieu, Suppl. 21: 1-224.

RutTNer, F., 1905: Über das Verhalten des Oberflächenplanktons zu verschiedenen Tageszeiten in Großen Plöner See. - ForschBer. biol. Stn. Plön. 12: 35-62.

- 1943: Beobachtungen über die tägliche Vertikalwanderung des Planktons in tropischen Seen. Arch. Hydrobiol. $40: 474-492$.

Ruttner-Kolisko, A., 1974: Plankton Rotifers: Biology and Taxonomy. - Die Binnengewässer 26: I suppl. Stuttgart.

-1975 a: The vertical distribution of plankton rotifers in a small alpine lake with a sharp oxygen depletion (Lunzer Obersee). - Verh. Internat. Verein. Limnol. 19: 1286-1294.

$-1975 \mathrm{~b}$ : The influence of fluctuating temperature on plankton rotifers. A graphical model based on life data of Hexarthra fennica from Neusiedlersee, Austria. - Symp. Biol. Hung. 15: 197-204.

Schinder, D. W., and B. Novín, 1971: Vertical distribution and seasonal abundance of zooplankton in two shallow lakes of the Experimental Lakes Area, Northeastern Ontario. - J. Fish. Res. Bd. Can. 28: 245-256.

Stern, J. R., 1973: Handbook of Phycological Methods: Culture Methods and Growth Measurements. - Univ. Press, Cambridge. 448 p.

Stemberger, R. S., 1974: Spatial and temporal distribution of rotifers in Milwaukee Harbor and adjacent Lake Michigan. - Proc. 17th Conf. Great Lakes Res., Internat. Assoc. Great Lakes Res. : $120-134$.

Strickler, J. R., and A. K. BAL, 1973: Setae of the first antennae of the copepod Cyclopss scutifer (SARS): their structure and importance. - Proc. Natl. Acad. Sci. USA 70: 2656-2659.

Thim nemane, A., 1919: Uber die vertikale Schichtung des Planktons im Ulmener Maar und die Planktonproduktion der anderen Eifelmaare. - Verh. Naturf. Ver. Preuss. Rheinl. 71: 103-134.

Vollenweider, R. A., 1969: A Manual on Methods for Measuring Primary Productivity in Aquatic Environments. - IBP Hindbook 12, Int. Biol. Programme, Blackwell, London.

G. W. FAIRChILD

Department of Ecology \& Evolutionary Biology, The University of Michigan, Ann Arbor, MI 48109 , USA

R. S. STEMBERGER

The University of Michigan Biological Station, Pellston, MI 49769, USA

L. C. Erskaim

School of Natural Resources, The University of Michigan, Ann Arbor, MI 48 109, USA

H. A. Debaugh, Jr.

14: Longview Drive, Baltimore, MID 21228. USA

Manuscript accepterl: September $15 \mathrm{th}, 1976$ 